\title{
Theoretical Links Between Natural Sciences Teaching and Human Rights: Proposals for a Humane Formation Perspective
}

\author{
Hanslivian Correia Cruz Bonfim \\ Brazil \\ Orliney Maciel Guimarães \\ Brazil
}

In this theoretical article, we discuss the ways of articulating Human Rights and the teaching of Natural Sciences in the early years of elementary school, in a perspective focused on the humane education. The theoretical basis for further discussion of the proposed subject matter was carried out through bibliographic research, having as sources: books, scientific articles and official documents. From this research, we proposed some topics that are related to human rights and are possible to be articulated with the contents of Natural Sciences developed in the early years. We consider that these topics need to be based on structuring axes that will base the pedagogical work of the teachers, so that they have as purpose the humane education of the students. These axes are: to become aware of the recognition of social, cultural and economic differences; to recognize oneself as a citizen with rights and to respect the right of the other; to plan and develop inclusive practices; to value the interrelationship between human beings and natural environments. We consider that the pedagogical work aimed at this perspective needs to be based on a dialogical and participatory methodology, with an emphasis on a humane and socially responsible education.

Keywords: Natural Sciences; Human rights; Humane education; Elementary School.

\section{Introduction}

Human rights are considered fundamental rights of the human person, as well as those "minimum rights for a human being to live in society" (Siqueira Júnior \& Oliveira, 2010, p. 22). The violation of human rights can be seen in different institutions, such as families, public agencies, churches and even at school (MEC, 2012). At school, we can perceive several situations that are related to issues of lack of respect, intolerance and lack of empathy, often generating violence among students and students-teachers. The issues related to the non-compliance with human rights in society become evident when observed more closely, since they are often naturalized and are not perceived as violations of human dignity, which consists of a principle of Rights Humans. In view of this issue of social urgency, we consider it essential that subject matters that refer to Human Rights are discussed in different disciplines, not only in the disciplines of human

1 All quotations in this article were translated - from Portuguese to English - by the author. 
and social areas, but also in the area of Natural Sciences. This is because we consider that many contents of the disciplines contemplating this area are possible to be articulated with the issues related to human rights.

This article is part of a doctoral research that is under development. It is a theoretical production based on bibliographic research, having as sources: books, publications in journals and official documents (Carvalho et. al., 2019). The objective of the study consists of discussing ways of articulating topics focused on human rights and Natural Sciences in the early years of elementary school, in a perspective focused on the humane education, based on the Human Rights Education. The first stage of this bibliographic search consisted of seeking information in the document entitled National Curriculum Guidelines for Human Rights Education (MEC, 2012), in order to understand what this document advocates about the pedagogical work focused on Human Rights Education (HRE) in basic education. Subsequently, the objective was to articulate HRE and the curriculum, with the purpose of understanding the several issues that need to be considered when reflecting on a curriculum based on multiculturalism and HRE. This stage was based on the following authors: Arroyo (2013), Candau (2008, 2013), Lopes and Macedo (2011), Moreira and Silva (2005), Moreira and Candau (2007), Silva (2005) and Silva (2014) - who we consider important references when discussing issues related to multiculturalism, in an intercultural view, and human rights. The last stage consisted of discussing the articulation of the teaching of Natural Sciences in the early years to Human Rights, which was based on the authors who discuss the teaching of Science and the education for citizenship and some authors who work with teaching and Science in the early years: Chassot (2000), Fabri and Silveira (2013), Lorenzetti and Delizoicov (2001), Oja and Bastos (2013), Porto and Porto (2012), Soares, Mauer and Kortmann (2013), Viecheneski and Carletto (2013); as well as authors who defend ways of developing sensitive listening in the early years (Arroyo, 2013; Oliveira, 2013). From these authors, we present suggestions on topics that we consider possible to be developed at this stage of schooling and that interface with Human Rights. In this last stage, we also proposed some structuring axes that we consider important to be present in these discussions for an education focused on the humane aspect.

We consider that education has as its objective not only the individual's cognitive formation, but also his or her humane and socially responsible formation. Forming individuals who are more supportive, more tolerant, respectful and who have the ability to put themselves in the other's place, is also a role of the school. For this, it is essential that discussions on this topic are thought and planned in the educational institution, including in the classes of Natural Sciences in the early years of Elementary School.

This article is divided into the following topics: Human Rights Education and Curriculum; the teaching of Natural Sciences and Human Rights and, finally, the final considerations. 


\section{Human Rights Education (HRE) and Curriculum}

We start from the premise that it is important to understand the transformations of society throughout history, as these changes create new demands for schooling, and that, therefore, the practices developed in educational institutions need to be consistent with these transformations. Imbernón (2016) explains that, "[...] throughout the twentieth century and up to the present moment of the twenty-first century, society has become more complex, therefore, exercising the role of the teacher has also assumed great complexity [...]" (p. 34). This author also considers that both the roles of the basic education teacher and the students have changed throughout history, and the same has happened with the society in which we are inserted. In this sense, the author highlights that:

It went from the old roles of instructing children in the four operations and learning to read and write, to a broader, more complete education that embraces all aspects of children: physical, emotional, intellectual, social.... Teachers are no longer those people who, using a single encyclopedic book (for all subjects), taught the basic questions in order to have access to culture. In the twenty-first century, they have become education and knowledge professionals because social issues are very important. (Imbernón, 2016, p. 51).

For this author, many aspects of society need to be learned and understood in the school context. He also points out that in this space it is important to develop respect towards oneself and also towards others, whoever they are, as well as respect for the environment in which they live. We consider that these issues are important for the student's humane and socially responsible education. Imbernón (2016) adds that it will be essential to develop in teachers and children "respect and tolerance, two concepts that will play a fundamental role in the world that we have been building day by day" (Imbernón, 2016, p. 52). However, how to develop these concepts in the teaching of Natural Sciences in the early years of elementary school? We consider that the contents developed in the early years in Natural Sciences are often limited to the conceptual contents, and the social, cultural and political issues are left to the teachers who work in the curricular components focused on the human and social area. In the National Guidelines for Human Rights Education (MEC, 2012) it is highlighted that Human Rights Education:

[...] aims to educate children, young people and adults to participate actively in the democratic life and to exercise their rights and responsibilities in society, also respecting and promoting the rights of other people. It is about an integral education that seeks mutual respect, for the other and for different cultures and traditions. (MEC, 2012, p. 496).

In the aforementioned document, it is explicit that Human Rights Education "needs to cross the curricula, daily relationships, gestures, 'pedagogical rituals, management models" (MEC, 2012, p. 501). It also complements that one of the ways to 
make it effective in the educational context can also happen through the (re) production of knowledge related to the defense and promotion of human rights. The main purpose of Human Rights Education aims at the ethical, critical and political education of students.

The National Curriculum Guidelines for Basic Education (MEC, 2013) highlights that, in order to achieve social inclusion, school education must be based on "ethics and values of freedom, social justice, plurality, solidarity and sustainability" (p. 16). Thus, the full development of students is achieved, in all dimensions, contributing to the formation of citizens aware of their rights and duties and who are committed to social transformation.

For McCowan (2015), HRE can help people change their attitudes and behaviors because "an individual can develop respect for the opinions of others, recognize the interests of those who are outside their immediate community, ethnic group or nationality, and refrain from submitting others, for example, to physical aggression or psychological humiliation" (p. 34). The author also reiterates that HRE can be understood as a means to defend the human rights of the student itself, that is, "the acquisition of information on the instruments of international right, the development of communication skills to negotiate with the authorities and the dispositions to act courageously in defense of their rights" (p. 34). It is important to emphasize that Human Rights Education will encompass both the ability of individuals to defend and exercise their rights, as well as that of respecting and acting in favor of the rights of others. In this sense, "HRE becomes a right for everyone and not just for the most excluded ones (although the need for the latter may appear with a more immediate demand). The construction of a human rights culture implies the involvement of everyone in the approval of rights" (McCowan, 2015, p. 37).

The National Curriculum Guidelines for Basic Education (MEC, 2013) highlights Caring and Educating as two inseparable actions for the purpose of a humane education, having the student as the center of the educational process. Thus, educating and caring begin in the first stage of basic education and need to extend to high school and further studies. Caring and educating means understanding that the right to education comes from the principle of the formation of the person in their human essence. In this perspective, caring must be considered in the sense of welcoming all students, regardless of their age and physical, social and cultural condition, "with respect and adequate attention to students with disabilities, young people and adults lagging behind at school, indigenous, Afro-descendants, quilombolas and rural peoples" (MEC, 2013, p. 17). In addition, "educating with care means learning to love without dependence, developing human sensitivity in the relationship of each one with oneself, with the other and with everything that exists, with zeal, in the face of a situation that requires caution in search for a full humane education" (MEC, 2013, p. 17).

This view of education, based on these two inseparable actions, agrees with an Education focused on Human Rights, in an "intercultural" perspective (Candau, 2013). In this view, educating and caring has as guiding principles the recognition of 
the "other", the respect for oneself and others, tolerance, ethics, cooperation, solidarity and otherness, which are fundamental issues to live in a collective. Thus, the scope of Human Rights Education is for the individual and/or social group to know him/herself as a person who has rights, as well as "being able to exercise and promote them while recognizing and respecting the rights of the other. HRE also seeks to develop ethical sensitivity in interpersonal relationships, in which each individual is able to perceive the other in his/her human condition" (MEC, 2012, p. 503).

In this perspective, the educational process has an important role for human education in all its dimensions, in the sense of having an education focused on social responsibility, that is, people who are capable of acting in their social context, with autonomy and freedom, in addition to make decisions and participate in public decisions in the country.

In this article, we support an education focused on Human Rights whose core is to educate and care as two inseparable, complementary and important actions to be present in the school context, an education that is inclusive and promotes learning. Schools can be considered as social microcosms, in which diversities meet. In these contexts, there are different ways of seeing the world, different values and needs, economic, social and cultural differences and various beliefs. Living with this diversity can generate conflicts, which are inseparable from human coexistence. In this sense, educational institutions need to critically analyze this reality, allowing different ways of seeing the world to come closer and confront each other, through "democratic processes and ethical and dialogical procedures, always aiming to face injustices and inequalities" (MEC , 2012, p. 504). We believe that, in this way, the school will help to educate critical people with the capacity to analyze and evaluate reality, based on Human Rights. Silva (2014) points out that the "[...] challenge that is posed today for human rights education seems to be to build a curriculum that allows us to leave the logic that teaches diversity to advance in the consolidation of a practice that we experience diversity" (p. 43).

In this sense, we consider that Human Rights should be an important subject matter to be present in the school curriculum, being lived in educational institutions, by students, staff, teachers and families.

Regarding the curriculum, Moreira and Silva (2005) point out that it is no longer seen only from a technical perspective, related only to procedures and methods, and argue that one can now speak of a "curriculum critical tradition, guided by sociological, political and epistemological issues" (p. 7). In this sense, there is a questioning about the way school knowledge is organized. For Apple (2005), the curriculum cannot be considered as a set of neutral knowledge, resulting from a cultural selection of an individual or from the vision of a certain group about what is legitimate knowledge. Thus, the curriculum can be considered as "a social and cultural artifact. This means that it is placed in the broader frame of its social determinations, its history, its contextual production" (Moreira \& Silva, 2005, p. 7). Therefore, the curriculum cannot be considered as neutral or innocent in relation to the transmission of school knowledge. In this sense, 
the curriculum cannot be analyzed without taking into account its social and historical constitution. Thus, the knowledge organized to be transmitted in schools, "is seen not only as involved in the production of asymmetric relations of power within the school and society, but also as historically and socially contingent" (Moreira \& Silva, 2005, p. 21). For Silva (2005), when thinking about curriculum, one must not forget that the knowledge that constitutes it is involved "in what we are, in what we become, in our identity, in our subjectivity. Perhaps we can say that, in addition to being a matter of knowledge, the curriculum is also a matter of identity" (p. 16). In a similar perspective, Moreira and Candau (2007) state that:

[...] the discussions about the curriculum incorporate, with greater or lesser emphasis, discussions about school knowledge, about procedures and social relations that shape the scenario in which knowledge is taught and learned, about the transformations we desire for students, about the values we wish to inculcate and about the identities we intend to build. (Moreira \& Candau, 2007, p. 18).

Therefore, it is important to highlight that, when discussing curriculum, issues related to identity and to difference are also discussed, as the curriculum refers to a humane education.

Candau (2013) points out that issues related to education and culture are important to be problematized. In addition, he highlights that the homogeneous and monocultural characteristics of the school are still strong in the current context, but that there is also an awareness of the importance of breaking with such characteristics and of building educational practices that are more focused on difference and multiculturalism. For Lopes and Macedo (2011), multiculturalism can be considered as a "description of the contemporary society" (p. 187), and can be understood to indicate the "plural feature of contemporary western societies" (Moreira, 2002, p. 16), the current world situation, which cannot be ignored.

In the perspective of the multiculturalism idea, the school must be seen as a "fluid and complex place, crossed by tensions and conflicts, intertwining cultures" (Candau, 2013, p. 14). This author also adds that, when thinking about the school in this way, it is necessary to reflect on the "different components and to break with the homogenizing and standardized tendency that permeates their practices" (Candau, 2013, p. 16).

Candau (2013) states that teachers cannot ignore cultural issues present in the school context because if there is this lack of knowledge, consequently, there may be a school that is distant from the symbolic and subjective issues of the students. Arroyo (2020) explains that, in the school curriculum, many times, "human experiences and the diversity of their subjects are ignored, only some experiences, some subjects and knowledge are considered valid, universal, legitimate" (p. 77). However, it would be essential - and we agree with this author - to include in the school curricula the social experiences of the agents involved in the educational process, making the school a space for inclusion and not for segregation. Brazil has its own configuration in relation to multiculturalism, as the country is constituted by a strong multicultural base, in which 
interethnic relations are constant when analyzing history, which was painful, especially when it comes to indigenous and Afro-descendants groups. In this way, it is understood that the historical formation of Brazil is "marked by the physical elimination of the 'other', or by its enslavement, which is also a violent way of denial of its otherness, the processes of denial of the 'other' are also in the social representations and imaginary" (Candau, 2013, p. 17).

Education needs to be focused on the inclusion of differences, and Imbernón (2016) reiterates the importance of understanding multiculturalism, which would be to recognize society as "plural and differentiated and the need to act respectfully, but it is also the promotion of different cultures. It is not diluting the diversified cultures, but respecting and sharing them. Respecting foreigners, but also native ones" (p. 69). The author also points out that school culture was not designed for the multiculturalism of individuals, but for generalization, having as its character an assimilationist model, "depriving a group of its right to be educated with the same guarantees as citizens" (Imbernón, 2016, p. 71). But how to change teachers' attitudes and the institutional organization, which often reinforce the exclusion of many students in the school context and reproduce the dominant social culture in a standardized way? In this work, we defend an intercultural perspective of education, as advocated by Candau (2013), which needs to be focused on the recognition of the "other", based on the dialogue between different social and cultural groups, therefore, in a movement of cultural negotiation, in a context characterized by power asymmetry.

The intercultural view, in our perspective, needs to be present in the school context, in order to recognize the differences without denying or naturalizing them, but in line with the discussions previously held about the two inseparable and complementary actions that are caring and educating. Candau (2013) highlights the importance of recognizing cultural identities, and that this identification can begin from the early years of the school process, in the sense of seeking the cultural roots of the students' families and their social lives, such as, for example, the neighborhood in which they live, the communities to which they belong, which institutions they attend, etc. The purpose would be to value the different characteristics of each person or social and cultural group.

The author also highlights the importance of "unveiling cultural color-blindness" that is present in the school. This color-blindness is characterized by not recognizing the differences present in the school, such as ethnic, gender, social and regional origin, etc., and ignoring the richness of this diversity in the classroom. We believe that this situation occurs because often teachers are not prepared to work with these differences, and because they believe that the most correct way is to treat everyone as equal, as a standard group. Thus, frequently, when naturalizing differences, they end up being silenced, and are not considered as challenges for a problematizing and meaningful educational practice for students. Moreira and Candau (2007) explain that color-blindness ends up preventing teachers from recognizing the "presence of diversity (and its consequences) 
at school" (Moreira \& Candau, 2007, p. 31).

In the school context, it is also possible to observe discrimination, racism, which appear on different manifestations. For this reason, male and female teachers have the fundamental role of creating spaces for relationships to be intercultural in a positive way, which does not eliminate conflicts. The objective is that students put themselves in the place of the other, and that the situations of prejudice, discrimination and racism present in the school are not trivialized, but rather problematized, in moments of collective reflection, from real situations that arise at school. For Silva (2014), "human rights education will only find useful ground as long as identities, narratives and non-hegemonic knowledge also find acceptance in the curriculum and pedagogical practices", and adds that "the equality of conditions and rights depends on the school radically recognizing the plurality that manifests inside it" (p. 47). Consequently, it should generate a change in the curriculum approach, because it should aim at the development of subjects with rights. In this sense, the school "should promote, in personal and collective terms, the development of subjects of rights capable of knowing, claiming and fighting for their rights" (Silva, 2014, p. 48).

It is necessary to highlight the importance of "conceiving pedagogical practice as a process of cultural negotiation" and, in this sense, for this to happen, it is important to highlight the "historical-social anchoring of the contents". In other words, the knowledge that is worked on at school needs to be seen as historical, and not just as facts and concepts, acquiring, in most cases, social legitimacy and becoming absolute truths. The school is formed based on "the affirmation of knowledge considered universal, a universality that is often formal and that, if we go a little deeper, ends up being based on Western and European culture, considered as a carrier of universality" (Candau, 2013, p. 33).

The curriculum, therefore, cannot deny non-hegemonic identities and belongings. It is necessary to understand that "the promotion of a human rights culture requires revisiting the curriculum and the hegemonic school culture itself, historically based on the idea of universality of knowledge and of the subjects of education" (Silva, 2014, p. 43). However, the multiculturalism matter arises to rethink the universalism matter, questioning the kind of universality. Nonetheless, it cannot be reduced to absolute relativism, limiting knowledge only to a cultural universe, which would lead to "denying the very possibility of building something together, negotiated between the different ones" (Candau, 2013, p. 33). In this perspective, Candau (2013) defends the idea that it is important:

[...] to unveil the historical and constructed character of school knowledge and its intimate relationship with the social contexts in which they are produced. It forces us to rethink our choices, our ways of building the school curriculum and our categories for analyzing the production of our students. (Candau, 2013, p. 33).

In the intercultural view, the curriculum encompasses different cultural universes and, in this sense, it is important to "rewrite school knowledge" (Moreira \& Candau, 
2007, p. 32). The authors explain the necessity of:

[...] hidden interests to be identified, evidenced and subverted, so that we can then rewrite the knowledge. We wish the student to realize how much, in Geography, the knowledge referring to the different continents was built in close association with the interest of certain countries in increasing their wealth by conquering and colonizing other peoples. (Moreira \& Candau, 2007, p. 32).

Moreira and Candau (2007) highlight that in the early years of elementary school it is also possible to mobilize students to:

[...] rewrite knowledge, myths, customs, legends, tales. Countless children's stories, for example, have been rewritten based on the use of points of view other than the usual ones. The case of the Three Little Pigs can be surprising if the Wolf represents the real estate speculator we know so well. The attitudes of the Cicada and the Ant can be reevaluated, keeping in mind the way work and leisure are conceived and organized in contemporary society. (Moreira \& Candau, 2007, p. 34).

In this sense, the authors' idea is not to substitute one knowledge for another, but to contribute so that students understand the power relations that are present in the hierarchy of knowledge and in cultural manifestations. In this perspective, it is important to "conceive the school as a space for criticism and cultural production" (Candau, 2013, p. 35), that is, the school is a space in which different cultural expressions and different languages are present and are produced. Thus, teachers need to favor experiences of cultural production and expansion of the cultural horizon of students, taking advantage of the resources available in the school community and in society. For this to happen, the school needs to be open to the different manifestations of popular culture, as well as to erudite culture. In this sense, "popular songs, dances, films, television programs, popular parties, advertisements, games, plays, poems, magazines and novels must be present in classrooms" (Moreira \& Candau, 2007, p. 41). Also, the knowledge closest to the dominant groups, with the objective of expanding the students' repertoire, so that there is, therefore, an interaction between these cultures. In this case, the objective "is that the culture of students and the community can interact with other events and other cultural spaces such as museums, exhibitions, cultural centers, classical music, classics of literature" (Moreira \& Candau, 2007, p. 41). Thus, the authors emphasize that, for this to happen, it is necessary for the teacher, as an intellectual, to be a "cultural critic" in relation to the culture in which he/she is immersed. In this view, the school needs to organize its pedagogical proposals in order to question what seems natural in the social context. In this sense, it is important for the student to understand the social order of which he/she is a part, thus challenging the existing one: "They may not change the world, but they can allow the student to understand it better" (Moreira \& Candau, 2007, p. 42).

Therefore, this process of criticism is necessary to rethink the conceptions that are implicit in cultural components, which teachings and ways of thinking are present, and to problematize these issues that are fundamental for students to have an ethical, 
political and critical education, as suggested by the National Guidelines for Human Rights Education (MEC, 2012).

According to the aforementioned document, it is important that the school curriculum include content that is articulated with the social, environmental, political and cultural reality, and that they dialogue with the realities close to and experienced by students in a critical and reflective way.

From the discussions held, we understand the importance of an intercultural education, which has as its core the consideration of the "other" in the pedagogical practice, as well as in the relationships established at school. Candau (2013) presents several issues that need to be rethought when reflecting on the curriculum, which is based on multiculturalism and on Human Rights Education. These issues need to be taken into account when developing Natural Sciences content in the early years of elementary school, this being the discussion held in the next topic.

\section{Natural Sciences Teaching, Human Rights and Citizenship}

According to Lorenzetti and Delizoicov (2001), it is important that children, from the early years, have access to scientific knowledge to develop a better understanding of situations that are part of their daily lives and so that they can make more appropriate decisions in their social context. In this sense, Science education plays an important role "in people's lives, as it can provide students with minimal knowledge to guarantee human needs, as well as health and environmental issues. The more informed and attentive the citizens are, the more successful they will be in decision making" (Soares et al., 2013, p. $51)$.

Regarding the exercise of citizenship, Viecheneski and Carletto (2013) emphasize that:

It is worth mentioning that attitudes and values are built from an early age and when the school provides moments for debates, questionings, reflections, exposure and confrontation of ideas, it opens the opportunity to teach values essential to the exercise of citizenship, such as respect for different ideas, tolerance, cooperation, respect for diversity, the rules agreed within the group, ability to communicate, to listen and to wait for their turn to express themselves, responsibility, critical sense and social inclusion. (Viecheneski \& Carletto, 2013, p. 223).

Therefore, it is understood that the teaching of Natural Sciences cannot be restricted to the transmission of information and the filling out of questionnaires, but it needs to be carried out considering the existing diversity in the classroom. For this, teachers should create an environment for children to position themselves, to question, to ask, to observe, to investigate and to solve problem situations. Teaching based on experiences that bring meaning to children, promoting the construction of knowledge. Teaching science at this stage "is of great importance, as it is during this period that the child builds, improves and reconstructs concepts about themselves and the world around them, relating what is taught at school to what is observed and learned in their 
everyday life" (Porto \& Porto, 2012, p. 29).

We understand that one of the goals of Natural Sciences is for children to reassess their knowledge and expand their worldview, and to be able to make decisions in their social context, seeking a better quality of life. In this case, the best quality of life refers to the child's daily situations, such as, for example, being aware of healthy eating, understanding the importance of preserving nature. In addition, we can mention proper separation of waste, knowing how their body is structured and how it should be respected and cared for, understanding individual, social and cultural differences and knowing how to respect these differences, etc. That is, issues that need to be understood and that will influence future decisions and developing ways of living in the social context.

The teaching of Natural Sciences in the early years of elementary school also needs to discuss issues related to the impacts of Science and Technology on society and the environment. According to Fabri and Silveira (2013), "the teacher, together with the class, needs to address pertinent curricular topics, which are part of the experience of the students and, from there, to develop a work related to Science and Technology, its impacts, its advantages and disadvantages" (p. 79).

In this sense, when the teacher develops in the classroom, for example, the content Water, he/she can discuss important concepts such as water on the planet, identifying water in living beings, in the soil, in the air, in the oceans, and elsewhere; the different states of water on the planet; the water cycle, etc. The teacher will also be able to discuss issues related to energy generation, such as, for example, the construction of hydroelectric plants and the extent to which these constructions can have negative consequences for the environment in which it is being built, both for the people who live there and for the other living beings that inhabit the region. Thus, they can discuss the advantages of these constructions - the generation of electrical energy for people, but also their disadvantages for the environment. We believe that these discussions are important when seeking Human Rights Education, because it is essential to have an ecologically balanced environment, in order to ensure that other human rights are not violated, such as health, well-being, food, work, etc., understanding the indivisibility of human rights.

Fabri and Silveira (2013) also emphasize that there is a need for a scientific education that prepares the student to understand about the:

[...] scientific and technological progress reflecting on the impacts, in conditions to position oneself in a conscious and responsible way in the face of the situations that emerge around them, from the initial years to higher levels, transforming common sense knowledge into more elaborated knowledge. (Fabri \& Silveira, 2013, p. 79).

Therefore, we understand the teaching of Science as fundamental to contribute for students to have:

[...] critical and reflective education in the face of current decisions and discussions involving scientific and technological knowledge, its causes, consequences, economic and political interests; it has become part of the roles that schools can play at the 
beginning of basic education. Science teaching in this school stage can contribute to the insertion of the student in an atmosphere of understanding the reality that surrounds them from a perspective that favors the contextualization of scientific knowledge, based on the conception of science as human production. (Oja \& Bastos, 2013, p. 5).

Therefore, understanding the reality, from discussions focused on decisions related to scientific and technological knowledge, the causes and consequences, unveiling the interests that are involved in these decisions, must be initiated in the early years of elementary school, contributing to the development of more critical and reflective individuals.

Human Rights Education focuses on promoting education for social change and transformation. Its main objective is "education for life and for coexistence, in the daily exercise of the Human Rights as a way of life and of social, political, economic and cultural organization in the regional, national and planetary levels". This objective should be the way for educational institutions to organize their Human Rights Education actions, "adequate to the needs, the biopsychosocial and cultural characteristics of the different subjects and their contexts" (MEC, 2012, p. 1).

We consider, based on this central objective of Human Rights Education, that teachers need to understand what Human Rights are, their principles and how they are articulated with the contents developed in the classroom; in addition, to develop practices that promote students' active learning. Based on this premise, we consider that it is essential that these discussions at school not only take place in the disciplines of the social and human areas, but also in the disciplines related to the Natural Sciences, such as Science (in the early years of elementary school), Physics, Chemistry and Biology. That is because we understand that it is possible to articulate the contents of these curricular components with social issues.

The National Common Curricular Base (BNCC) (MEC, 2017) highlights that in order to develop scientific literacy ${ }^{2}$, it is necessary that the area of Science is articulated with other areas of knowledge. Based on this assumption, we understand that it is possible to articulate issues related to Human Rights in Science classes, in order to help students develop fundamental values and skills to build a more fair, democratic and inclusive society, as suggested by the BNCC. We consider it important that educational actions in the teaching of Natural Sciences can contribute for students to build "arguments based on reliable data, evidence and information and to negotiate and defend ideas and points of view that promote socio-environmental awareness and respect for themselves and the other, welcoming and valuing the diversity of individuals and social groups, without prejudice of any kind" (MEC, 2017, p. 324, emphasis added), meeting what is expected in relation to Human Rights Education. We believe that in the early years it is essential that children be heard in the classroom, that is, the teacher must create

2 In the different works related to Science teaching, the terms scientific literacy and scientific alphabetizing are addopted. In this article we refer to scientific literacy considering "[...] the importance of preparing the individual for life in a scientific and technological society, in which knowledge assumes an essential role, within a critical perspective of science and technology" (Mamed \& Zimmermann, 2005, p. 1). 
spaces to understand the students' previous knowledge. Oliveira (2013) highlights that the teacher needs to learn to listen to students and exchange information with them, and adds that:

[...] listening is not easy for those who were not used to it! It will be necessary for the teacher to train and exercise how to really hear the student's voice. Listening to the student does not end with the reproduction of the answers that the teacher wants to hear, but with the possibility for the student to express his/her own voice and, consequently, his/her worldview. (Oliveira, 2013, p. 65).

We believe it is essential, in Natural Sciences classes, to listen sensibly to the experiences that children bring to the classroom, that is, to give value to the "experiences of living" (Arroyo, 2013) of the childhoods that are part of the school. Arroyo (2013) highlights the different experiences that children can bring in their speeches as the "experiences of physical spaces" where they live, such as houses, streets, villages, countryside and others; the "experiences of living/surviving", such as food, family work, or unemployment, rights that are not guaranteed, such as the right to life, health, food, leisure, etc.; family-related experiences, such as different family arrangements; "experiences of protection, care or lack of protection", such as abandonment, abuse, among others. These experiences can and, in our opinion, need to be part of Science classes, so that they become more alive, closer to children. One of the ways of understanding these different experiences and valuing them is to give children a voice. Dialogue is the best way to seek and understand these experiences, and to link them to the contents of Natural Sciences, which we consider fundamental for an education focused on human rights. However, these "listening" are not always easy to do, due to the precarious and often inhumane situations that many children experience in their social context. Nonetheless, we believe that we cannot ignore these experiences without exploring them in Natural Sciences classes. Perhaps one of the ways to involve these experiences in educational practices is to go beyond the walls of the school, by observing the community in which these children are inserted, and by carrying out, for example, projects that make this articulation possible. For Chassot (2000), there is a "need to seek an appreciation of popular knowledge and an awareness of the respect they deserve and how they are inserted in different social contexts" (p. 207).

The BNCC document refers to teaching not only being based on the presentation of Natural Sciences content to students, but it is necessary that teachers plan moments for them to be involved in the processes of learning, especially those processes that encompass research, so that from there they expand their curiosity, exercising observation, logical reasoning and creativity. That is, in order to systematize their first explanations about the natural and technological world, and "about their body, their health and their well-being, having as reference the knowledge, languages and procedures of the Natural Sciences" (MEC, 2017, p. 331).

It is important to point out that the teaching of Natural Sciences is a child's right in the early years of Elementary Education, as recommended by the National 
Educational Guidelines and Framework Law No. 9394/96 (1996). In this sense, it is up to the teachers, with adequate planning, to expand students' knowledge, considering their age group. That is because we consider that, within the Natural Sciences teaching, it is possible for the students to reframe their knowledge, thus expanding their worldview, their understanding of the context in which they are inserted, enabling them to make more appropriate decisions in their daily lives, such as: choosing foods that bring health benefits, decisions about caring for their bodies, caring for the environment, understanding individual, social and cultural differences, and knowing how to respect those differences, etc.

At BNCC (MEC, 2017), in the Natural Sciences curricular component, there are the thematic units, knowledge objects and skills referring to the initial years of Elementary School. Regarding the initial years, starting from the thematic unit, it is possible and viable to develop subject matters that relate to Human Rights and Citizenship. In our view, they need to meet the goals for Human Rights Education defined by the National Guidelines for Human Rights Education (MEC, 2012). This document defines that one of the main purposes of defending Human Rights is the "construction of societies that value and develop conditions for the guarantee of human dignity" (MEC, 2012, p. 503, emphasis added). The Guidelines explain that Human Rights Education aims to contribute so that people or social groups recognize their rights, and that they are also able to exercise them in the social context, as well as respect the rights of others. Another objective of HRE is to develop sensitivity towards "interpersonal issues, in which each individual is able to perceive the other in his/her human condition" (MEC, 2012, p. 503 , emphasis added). Based on this document, which is a guideline for actions aimed at Human Rights in educational institutions, we can identify some important subject matters, in order to seek understanding about the rights of everyone and to develop a view and a listening more sensitive to the issues of difference, thus seeking better and more harmonious interpersonal relationships. The subject matters that we consider important to be developed in the early years in the teaching of Natural Sciences and which interface with Human Rights are Ethnic-racial relations; Environmental education; Sex, sexuality and gender ${ }^{3}$ and Bullying. However, we consider that they are based on structuring axes so that students can truly understand them and experience them in their educational context.

We consider that in this teaching stage it is possible to articulate the Science content with the topics mentioned above. To exemplify these possible relationships, we selected some objects of knowledge defined in the BNCC (MEC, 2017) and we proposed

3 Leal et al. (2017) explain that the concept of sex refers to both the reproductive organs, as well as their biological and chromosomal characteristics, thus they are biologically constructed issues, and complement that "the differentiation of the sexes begins biologically, and from there society, civil registry, families shape according to their sexual recognition" (Leal et al., 2017, p. 96). Sexuality is part of people's lives "involving individual, social, psychological and cultural aspects, which carry historicities, practices, attitudes and symbolizations" (Moizés \& Bueno, 2009, p. 206). Gender, on the other hand, is related to social issues "with social differentiation between people, with the possible construction and deconstruction, since it is from historical and cultural patterns that we define the behavior of women and men" (Leal et al. 2017, p. 96). 
some suggestions for making these articulations.

Regarding the objects of knowledge called "Human body and Respect for diversity", it is possible to discuss issues related to ethnic-racial relations with the purpose of understanding about the different cultures and their influences for the construction of our country; to seek the cultural origins of students; to identify the different cultural manifestations present in the community in which the school is inserted; to recognize the different visible phenotypic characteristics (the color and texture of hair and skin, height, etc.); to discuss concepts such as prejudice, discrimination and racism, etc. From these objects of knowledge, the teacher can also discuss questions about sex, gender and sexuality, developing discussions aimed at the respect for the different manifestations of sexuality; to the discrimination existing in the Brazilian context in relation to gender - this can be done with statistical data (tables, graphs) that demonstrate that, in our country, women still have lower salaries than men; the presence of women in science; violence towards women; female empowerment, and others.

Bullying $g^{4}$ can also be contextualized in the classroom, based on these objects of knowledge, such as the respect for differences, personal, cultural, religious characteristics, etc., why bullying occurs, what its characteristics are, what types of bullying exist, etc.

From the object of knowledge "Nutrition of the organism and eating habits", it is possible to articulate issues related to the different types of foods that originate from different cultures; to understand how eating habits are influenced by the culture to which we belong; how to use cutlery, or not to use it; how to behave at the table, etc., with emphasis on ethnic-racial relations.

Environmental Education can be present when the teacher is developing the objects of knowledge "Hydrological cycle, Conscious consumption and Recycling", as they can discuss social issues considered of social urgency, such as garbage and its proper disposal, electronic waste, consumption and how it generates more waste in our social context, water pollution and the need to preserve it for the health of people and other living beings, basic sanitation as a right, and other discussions that appear to be necessary. We emphasize that these topics could articulate with each other, that is, the teacher could discuss environmental issues related to indigenous culture, for example, or bullying related to the issue of homophobia. In this sense, for these articulations and discussions to be possible, it is essential that teachers, at this stage of teaching, understand about these topics and that they also allow the childhood experiences to be heard and considered in these discussions.

From Moreira (2002); Moreira and Candau (2007), Candau (2008; 2013), Candau and Sacavino (2013); and the National Guidelines for Human Rights Education (MEC, 2012), we propose some structuring axes that we believe are important to be present in discussions focused on Human Rights and its articulation with the teaching of Natural

4 Systematic intimidation when there is physical or psychological, intentional and repetitive violence that occurs without evident motivation, practiced by an individual or group, against one or more people, with the aim of intimidating or assaulting it, causing pain and anguish to the victim, in a power imbalance relationship between the parties involved. (Law No. 13,185, November 6, 2015). 
Sciences in the early years of Elementary school, for a humane education. These axes are: i) Becoming aware of the recognition of social, cultural and economic differences; ii) Recognizing oneself as a citizen with rights and respect the right of the "other"; iii) Planning and developing inclusive practices; iv) Valuing the interrelationship between human beings and natural environments.

Raising awareness in the recognition of differences is linked to the idea discussed by Moreira and Candau (2007) and Candau (2013) about "cultural color-blindness". For these authors, it is necessary to recognize differences in relation to gender, social, physical, cultural and ethnic conditions at school, which need to be problematized in the classroom. In this sense, it is essential that difference and equality be articulated. In this perspective, it is important that, in this teaching stage, there are moments focused on raising awareness, in the sense of putting oneself in the place of the other, of perceiving the differences that exist in the school. We believe that it is important to highlight, at this stage of teaching, respect for differences, emphasizing respect for others and tolerance. We understand that tolerance has a fundamental role for human relationships to be more harmonious. Thus, it can be understood that "tolerance is harmony in the differences" (Unesco, 1995, p. 11). This means that:

[...] tolerance is respect, acceptance and appreciation of the richness and diversity of the cultures of our world, of our ways of expression and of our ways of expressing our quality as human beings. It is fostered by knowledge, the opening of thought, awareness and belief. (Unesco, 1995, p. 11).

Therefore, sensitizing students to recognize and respect differences, in this teaching stage, helps them to rethink attitudes and behaviors, often experienced in their own families or in other institutions of which they are part, especially the school. Therefore, we consider it important to develop the practice of tolerance. "The practice of tolerance means that everyone has the free choice of their convictions and accepts that the other person enjoys the same freedom" (Unesco, 1995, p. 12).

Thus, raising of awareness, recognition, and the development of tolerance and respect for differences can begin in the first stages of basic education through children's literature books, starting with poems, music, videos, conversation circles, theaters, which could be good triggers for these discussions. Pedagogical work with the contents of Natural Sciences, such as, for example, the issue of the body, gender, the different manifestations of sexuality, personal differences, such as physical and cultural, are contents that are presented in the Natural Sciences curriculum component, which may have sensitization, recognition, respect and tolerance to differences as their structuring axis. This is because developing debates, discussions and reflections, having this axis as a principle, makes it possible to expand students' knowledge in relation to difference and identity - important issues that must be present in the curriculum.

The axis recognizing oneself as a citizen of rights and respecting the rights of the "other" is linked to the idea that it is important - in discussions on Human Rights, starting from the Natural Sciences content - to address social, political, economic, 
cultural and civil rights. That is for the children to have an understanding of these rights and to establish relationships with broader issues of society. It is also important that the discussions in the classroom aim at the recognition of the "other", meeting the first axis discussed, which is to realize that all individuals have rights, regardless of their ethnicity, economic, social, cultural condition, gender, etc., as stated in the Federal Constitution of 1988. However, understanding social asymmetry is also part of education, emphasizing political training, in the sense that everyone has equal rights, but not everyone has access to these rights, due to several factors, such as historical, social, economic and political. This can happen in the early years of elementary school, for example, with the analysis of statistical data, which can be problematized by the teachers so that the children can verify that the rights are equal and guaranteed by legal norms, but that in the real context these rights are not always respected due to several factors. To problematize with students, questions can be made, such as: "What can we do to reduce the gender pay gap in the world of work?" Thus, it is essential that the realities experienced by students are unveiled, and for that, teachers must have a sensitive listening to the experiences they bring to the classroom.

For pedagogical work focused on human rights and citizenship, an articulation of the concepts of prejudice, discrimination and racism is essential. This will help students to understand the importance of inclusive actions in the social context as well as in the educational institution, meeting the third structural axis, which is planning and developing inclusive practices. We consider that concepts such as prejudice, discrimination and racism need to be problematized in classrooms through various resources, such as, for example, strips that can enable reflections on prejudice and discrimination, theater organized by children and the teacher; children's literature book, among others. In this perspective, it is important for students in the early years of elementary school, through Natural Sciences content, to understand that prejudice is a pre-judgment, therefore, it is "an opinion or feeling that we adopt without prior reflection, without foundation or reason" (Borges et al., 2009, p. 53). For these authors, prejudices are present in the socialization process and it is very difficult to eradicate them. However, we understand that at school it is important to unveil the issues of prejudice, which often generate conflicts and aggressive attitudes towards others.

Problematizing these concepts contributes to students having more discernment to identify prejudiced and discriminatory practices in the social context, in the speeches of colleagues and teachers, as well as in cultural and media productions, such as advertisements that depreciate the figure of women, songs that support racism, etc. In short, these discussions contribute to the valorization of the human person. In this sense, "this person, due to his/her natural characteristics, because he/she is endowed with intelligence, conscience and will, because he/she is more than a simple portion of matter, has a dignity that places him/her above all things in nature" (Lodi, 2003, p. 16). Thus, respect for human dignity needs to be present in relationships, in all spaces and equally for all people (Lodi, 2003), as the preservation of dignity is part of the human 
rights. This axis also seeks to problematize issues related to violence, which is present in school contexts, such as, for example, the practice of bullying, which can be considered as a kind of school violence, according to Candau (2013). Therefore, it is essential that the school be an environment that promotes human rights, based on the "recognition of the need to respect differences, ensuring the accomplishment of democratic and inclusive practices, free from prejudice, discrimination, violence, harassment and sexual abuse, among other ways of violation of human dignity" (MEC, 2012, p. 504).

We believe that the axis planning and developing inclusive practices deals with two important concepts that need to be present in basic education: caring and educating. The teacher also needs to be aware of these concepts in schools and to develop inclusive actions so that children in the early years can experience what is an inclusive environment, free from prejudice, discrimination, racism and violence, that is, a welcoming environment, conducive to achieving learning rights, in which differences are valued. It meets the first and second axes discussed. We understand that these axes need to base the discussions on Human Rights in the Teaching of Natural Sciences, contributing to an ethical, political and critical education as defined by the National Guidelines for Human Rights Education (MEC, 2012).

The structuring axis valuing the interrelationship between human beings and natural environments and the importance of a healthy environment is related to the "Social and Environmental Sustainability" principle, discussed in the National Guidelines for Human Rights Education. It highlights the "incentive and promotion of a sustainable development that preserves the diversity of life and cultures, a condition for the survival of humanity today and of future generations" (MEC, 2012, p. 503). We consider that this axis is also articulated with what is defined in the Federal Constitution of 1988: "the right to an ecologically balanced environment, of common use of the people and essential to a healthy quality of life, impose to the public power and the community the duty to defend and preserve it for present and future generations" (Federal Constitution, 1988). From the issues mentioned above, it is understood that the social aspect is not disconnected from environmental issues. In this sense, Tiriba and Profice (2014) highlight that the environment is no longer only the subject of scientists, as it is part of the social movements that consequently "gave a new direction to the environmentalist thinking, especially in the definition of the priority of struggle. Currently, social inequalities are considered one of the most serious environmental problems to be faced by people, peoples and nations" (p. 57). Therefore, it is important to reflect on issues related to socioeconomic inequalities when it comes to environmental education.

Therefore, we consider that the content developed in the early years of elementary school, in the Natural Sciences curricular component, can be articulated with issues related to social and human values and with the respect for the diversity of life. Thus, it is possible for the teacher to develop practices that bring the child closer to nature, so that they understand the importance of living in harmony with the natural environment and, above all, that they understand about the importance of having a healthy environment as 
a human right. Bringing children closer to nature means providing conditions for them to be aware of the living world, and it can be a way of contributing to future generations being more committed to environmental problems. "If children do not interact with nature, their affinity with it is compromised, the attribution of its value, its affective appeal, its condition as a source of knowledge" (Tiriba \& Profice, 2014, p. 65). In this perspective, we believe that teachers who work in this curricular component promote practices that enable the child's experience and contact with nature, allowing them to have experiences with natural elements, such as water, land, air, through tour-classes in green spaces, planning the creation of gardens and vegetable gardens, observing natural spaces, etc. We also understand that topics such as the negative and positive consequences of Science and technology, as human productions, can be problematized in this axis, as previously discussed.

We also defend that Sex, Gender and Sexuality; Ethnic-racial relations; Bullying and Environmental Education, which interface with Human Rights, can be developed with the different contents of Natural Sciences in the early years of Elementary Education, and that these discussions need to be based on the structuring axes previously mentioned. We also believe that these axes should not be treated in a static way, but articulated with each other. Therefore, these axes dialogue with each other in order to contribute to a humane and socially responsible education.

According to Oliveira and Queiroz (2016), education for citizenship is linked to the idea of "developing universal social values". For this reason, these authors link the areas of Science Education and Human Rights Education, and emphasize that "for this aspired citizenship, all other areas must seek this type of relationship. Human Rights Education is Transversal to Education" (p. 69).

In agreement with Oliveira and Queiroz (2016), we consider that the pedagogical work focused on Human Rights Education and Citizenship needs to be guided by transversality, which can be understood as a way of organizing the "didactic-pedagogical work in which themes, thematic axes are integrators to the disciplines, to the so-called conventional areas in order to be present in all of them" (MEC, 2013, p. 29). In the National Guidelines for Human Rights Education (MEC, 2012) it is explicit that the organization of Basic Education curricula, focused on knowledge related to Human Rights, can happen in the following ways: through transversality, from topics focused on Human Rights and developed in an interdisciplinary way; specific content can also be organized, referring to a specific subject in the curriculum; and in a mixed way, which would be to link transversality and disciplinarity.

The perspective that we defend is the work based on transversality, as we believe that it is possible and viable to articulate scientific knowledge with social issues, which are present in daily life. We also defend that, in addition to these topics being developed in a transversal way with the contents of Natural Sciences, it is fundamental that the relations established in the school context are based on the respect and perception of the "other", on tolerance and, above all, based on the caring and educating, as inseparable and 
complementary actions, which were previously discussed. It is important to emphasize that schools are not the only spaces dedicated to educating people in Human Rights, but we reaffirm what is explicit in the National Guidelines for Human Rights Education, that these institutions have as "responsibility the promotion and legitimization of their principles as guide for social, ethical and political ties. This is done through the education of subjects with rights, capable of defending, promoting and claiming new rights" (MEC, 2012 , p. 503). We also believe that education is "one of the fundamental mediations for access to the historical legacy of Human Rights, as well as for the understanding that the culture of Human Rights is one of the foundations for social change" (MEC, 2012, p. 495). In this way, education can be considered as "one of the Human Rights and Human Rights Education is a fundamental part of the set of these rights, including the very right to education" (MEC, 2012, p. 495).

\section{Final Considerations}

The objective of this article was to discuss ways of articulating subject matters related to human rights, such as sex, gender and sexuality, bullying, ethnic-racial relations and Environmental Education with the contents of Natural Sciences in the early years of elementary school, in a perspective focused on a humane education. In view of this initial objective, we propose some structuring axes to support the practices carried out by teachers in order to seek education in human rights in the teaching of Natural Sciences. The structuring axes discussed in this work were: to become aware of the recognition of social, cultural and economic differences; to recognize oneself as a citizen with rights and respect the right of the "other"; to plan and develop inclusive practices; to value the interrelationship between human beings and natural environments. We emphasize that these axes are not static, as they articulate and complement each other at the time of the teacher's pedagogical practice. We also consider that these axes are not only structuring in the teaching process of Natural Sciences, but that in the daily actions and relationships established at school they need to be present.

We believe that this research and the discussions carried out throughout this text can contribute to the teaching of Science, so that the practices carried out by teachers of Natural Sciences in the early years of elementary school can be guided by a broader view of the contents they will develop in the classroom. This way, when planning, they can consider these issues and the structuring axes. We consider these discussions fundamental for the development of Human Rights Education. We also believe that many social injustices present in the Brazilian context are not solved by the school - as an institution that saves all problems. However, we consider it fundamental for these educational spaces to hold discussions about human rights, so the individuals involved in this process can develop the capacity to defend and exercise their rights, as well as respect and act in favor of the rights of others.

We also consider that in order to work with Bullying, Ethnic-Racial Relations, Sex, Gender and Sexuality and Environmental Education in the teaching of Natural 
Sciences, it is important that the methodology used is not focused on the transference of information, but that the teacher can develop in the classroom moments for reflection and dialogue. Therefore, the methodology should propose active participation of students, having as principles that they are builders of their own knowledge in a problematizing, interactive, participatory and dialogical way, therefore, giving emphasis to a critical education.

We understand that, in the early years of elementary school, it is important for the teacher to develop different strategies so that students can actively participate in the construction of knowledge based on Human Rights and Citizenship. In the early years of elementary school, it is important that the teacher develops practices with different languages, such as music, theater, videos, movement, literature, visual arts, etc., which can be triggers to problematize issues that interface with Human Rights and Citizenship in the teaching of Natural Sciences.

In Science education, for the teacher to be able to make this relationship with the specific contents of this curricular component with the issues focused on human rights, it is necessary that they understand what human rights are and its relationship with citizenship, and the importance of HRE for the formation of a culture of peace. Thus, we consider it important that they have specific training aimed at problematizing issues related to this subject matter. In this way, the result of the discussion undertaken here may contribute to the organization of continuous training based on an education focused on human rights, citizenship and Natural Sciences, as the subject matters presented in this work and the structuring axes may collaborate for the planning of these formations, in the sense of seeking a broader view of the Natural Sciences contents and their possible links with an education focused on a humane education. We also believe that this research can contribute to the initial training of future educators and educators who will work in this stage of teaching, who are often responsible for acting in the different curricular components, such as Mathematics, Geography, History, Science, Arts, etc., which is a specific feature of this teaching stage.

In this perspective, it is essential that discussions focused on human rights and citizenship be held in initial teacher training courses as well as in continuing training for those professionals who already work in the area of education. In this way, teachers or future teachers may have the possibility to reflect on their concepts, prejudices, thoughts, and their way of seeing the world, which were built in the process of socialization.

Regarding the implications for the area of Science teaching, we highlight that this theoretical study points to the need for empirical research, in order to evaluate the axes proposed in this work and to establish limits and possibilities of articulation between the teaching of Science and Rights Humans aiming at education for citizenship, not only in the initial years, but also at other levels of education. 


\section{References}

Apple, M. W. (2005). Repensando ideologia e currículo [Rethinking ideology and curriculum]. In A. F. B. Moreira \& T. T. Silva. da. Currículo, cultura e sociedade (pp. 39-58). Cortez.

Arroyo, M. G. (2013). Currículo, território em disputa [Curriculum, territory in dispute]. 5 ed. Vozes.

Borges, E., Medeiros, C. A., \& Adesky, J. d’ (2009). Racismo, preconceito e intolerância [Racism, prejudice and intolerance]. 7 ed. Atual.

Chassot, A. (2000). Alfabetização científica: Questões e desafios para a educação [Scientific literacy: Issues and challenges for education]. Ed. UNIJUÍ.

Candau, V. M. (2008). Direitos humanos, educação e interculturalidade: As tensões entre igualdade e diferença [Human rights, education and interculturality: The tensions between equality and difference]. Revista Brasileira de Educação, 13(37), 45-56. https:// doi.org/10.1590/S1413-24782008000100005.

Candau, V. M. (2013). Multiculturalismo e educação: Desafios para a prática pedagógica [Multiculturalism and education: Challenges for pedagogical practice]. In A. F. Moreira \& V. M. Candau. Multiculturalismo: Diferenças culturais e práticas pedagógicas (pp. 13-37). Vozes.

Candau, V. M. \& Sacavino, S. B. (2013). Educação em Direitos Humanos e formação de educadores [Human Rights Education and Educators Training]. Educação. 36(1), 59-66.

Carvalho, L. O., Duarte, F. R., Menezes, A. H. N., \& Souza, T. E. S. (2019). Metodologia científica: Teoria e aplicação na educação a distância [Scientific methodology: theory and application in distance education]. 1 ed. Universidade Federal do Vale do São Francisco.

Fabri, F. \& Silveira, R. M. C. F. (2013). O ensino de ciências nos anos iniciais do ensino fundamental sob a ótica CTS: Uma proposta de trabalho diante dos artefatos tecnológicos que norteiam o cotidiano dos alunos [Science teaching in the early years of elementary school from the CTS perspective: a work proposal in view of the technological artifacts that guide students' daily lives]. Investigações em Ensino de Ciências. 18(1), 77-105.

Imbernón, F. (2016). Qualidade do ensino e formação do professorado: Uma mudança necessária [Quality of teaching and teacher training: A necessary change]. 1. ed. Cortez.

Leal, N. C. Zoccal, S. I. L., Saba, M., \& Barros, C. R. S. (2017). A questão de gênero no contexto escolar [The gender issue in the school context]. (2017). Leopoldianum, (121), 95-104.

Lei no 9.394, de 20 de dezembro de 1996. (1996). Lei de Diretrizes e Bases da Educação Nacional [Law of guidelines and bases of national education]. Estabelece as diretrizes e bases da educação nacional. Diário Oficial da União. Brasília, DF: Presidência da República. 
Lei no. 13.185, de 6 de novembro de 2015. (2015). Lei do Bullying [Bullying Law]. Institui o Programa de Combate à Intimidação Sistemática (Bullying). Diário Oficial da União. Brasília, DF: Presidência da República.

Lodi, L. H. (2003). Ética e cidadania: Construindo valores na escola e na sociedade. Secretaria Especial dos Direitos Humanos [Ethics and citizenship: building values at school and in society]. MEC, SEF, SEMTEC, SEED.

Lopes, A. C., \& Macedo. E. (2011). Teorias do Currículo [Curriculum Theories]. 1 ed. Cortez, 2011.

Lorenzetti, L., \& Delizoicov, D. (2001). Alfabetização científica no contexto das séries iniciais [Scientific literacy in the early years context]. Revista Ensaio. 3(1), 45-61.

McCowan, T. (2015). O direito humano à aprendizagem e a aprendizagem dos direitos humanos [The human right to learning and the learning of human rights]. Educar em Revista. (55), 25-46.

Mamede, M., \& Zimmermann, E. (2005). Letramento Científico e CTS na formação de professores para o ensino de ciências [Scientific Literacy and CTS in teacher education for science teaching]. Enseñanza de las ciências, número extra. VII Congreso.

MEC (2012). Diretrizes Nacionais para a Educação em Direitos Humanos [National Guidelines for Human Rights Education]. Brasília: Secretaria da Educação Básica.

MEC (2013). Diretrizes Curriculares Nacionais Gerais da Educação Básica [General National Curriculum Guidelines for Basic Education]. Brasília: Secretaria da Educação Básica.

MEC (2017). Base Nacional Comum Curricular [Common Curricular National Base]. Brasília: Secretaria da Educação Básica.

Moizés, J. S., \& Bueno, S. M. V. (2010). Compreensões sobre sexualidade e sexo nas escolas segundo professores do ensino fundamental [Understanding sexuality and sex in schools according to elementary school teachers]. Revista da Escola de Enfermagem da USP, 44(41), 205-212.

Moreira, A. F. B., \& Candau, V. M. (2007). Indagações sobre o currículo: Currículo, conhecimento e cultura [Curriculum Inquiries: Curriculum, Knowledge and Culture]. Ministério da Educação. Secretaria de Educação Básica.

Moreira, A. F. B. (2002) Currículo, diferença cultural e diálogo diálogo [Curriculum, cultural difference and dialogue]. Educação \& Sociedade. Ano XXIII, 79, agosto, 15-38. http://dx.doi.org/10.1590/S0101-73302002000300003

Moreira, A. F. B., \& Silva, T. T. da. (2005). Sociologia e teoria crítica do currículo: uma introdução [Sociology and critical curriculum theory: an introduction]. In A. F. B. Moreira, \& T. T. Silva. Currículo, cultura e sociedade (pp. 7-38). Cortez. 
Oja, A. J., \& Bastos, F. (2013). Ensino de ciências no início da educação fundamental: Algumas implicações para uma educação científica de qualidade qualidade [Science teaching at the beginning of elementary education: some implications for quality science education]. In Encontro Nacional de Pesquisa em Educação em Ciências (p. 1). Água de Lindóia, SP.

Oliveira, R. D. V.L. de., \& Queiroz, G. R.P.C.(Org.). (2016). O cotidiano, o contextualizado e a Educação em Direitos Humanos: A escolha de um caminho para uma Educação cidadã cosmopolita cosmopolita [The daily life, the contextualized and the Education in Human Rights: the choice of a path for a cosmopolitan Citizen Education]. In R. D. V. L. Oliveira \& G. R. P. C Queiroz. Tecendo diálogos sobre direitos humanos na educação em ciências (pp. 63-98). Editora Livraria da Física.

Porto, A. \& Porto, L. (2012). Ensinar ciências da natureza por meio de projeto: Anos inicias do ensino fundamental [Teaching natural sciences through projects: Early years of elementary school]. 1 ed. Rona.

Silva, A. T. R. da. (Org.). (2014). Educação em Direitos Humanos: O currículo entre o relativismo e o universalismo [Human Rights Education: The curriculum between relativism and universalism]. In A. T. R. da Silva (Org.). Leituras críticas em Educação e Direitos Humanos (pp. 20-50). Liber Livro; Alia Opera.

Silva, T. T. da. (2005). Documentos de Identidade: Uma introdução às teorias do currículo [Identity Documents: An Introduction to Curriculum Theories]. 2 ed. Autêntica.

Siqueira Júnior, P. H., \& Oliveira, M. A. M. de. (2010). Direitos Humanos e Cidadania [Human Rights and Citizenship]. 3 ed. Revista dos Tribunais.

Soares, A. C., Mauer, M. B., \& Kortmann, G. L. (2013). Ensino de ciências nos anos iniciais do ensino fundamental: Possibilidades e desafios em Canoas-RS [Science teaching in the early years of elementary school: Possibilities and challenges in CanoasRS]. Revista Educação, Ciência e Cultura, 18(1), 49-61.

Tiriba, L. \& Profice, C. (2014). O direito humano à interação com a natureza. In A. M. M. Silva, \& L. Tiriba (Org.). Direito ao ambiente como direito à vida: Desafios para a educação em direitos humanos natureza [The human right to interaction with nature] (pp. 47-77). Cortez.

Unesco. (1995). Declaração de Princípios sobre a Tolerância [Declaration of Principles on Tolerance]. Unesco General Conference at its 28th meeting. Paris.

Viecheneski, J. P., \& Carletto, M. (2013). Por que e para quê ensinar ciências para crianças [Why and what for teaching Science to children]. Revista Brasileira de Ensino de Ciência e Tecnologia, 6(2), 213-227. 


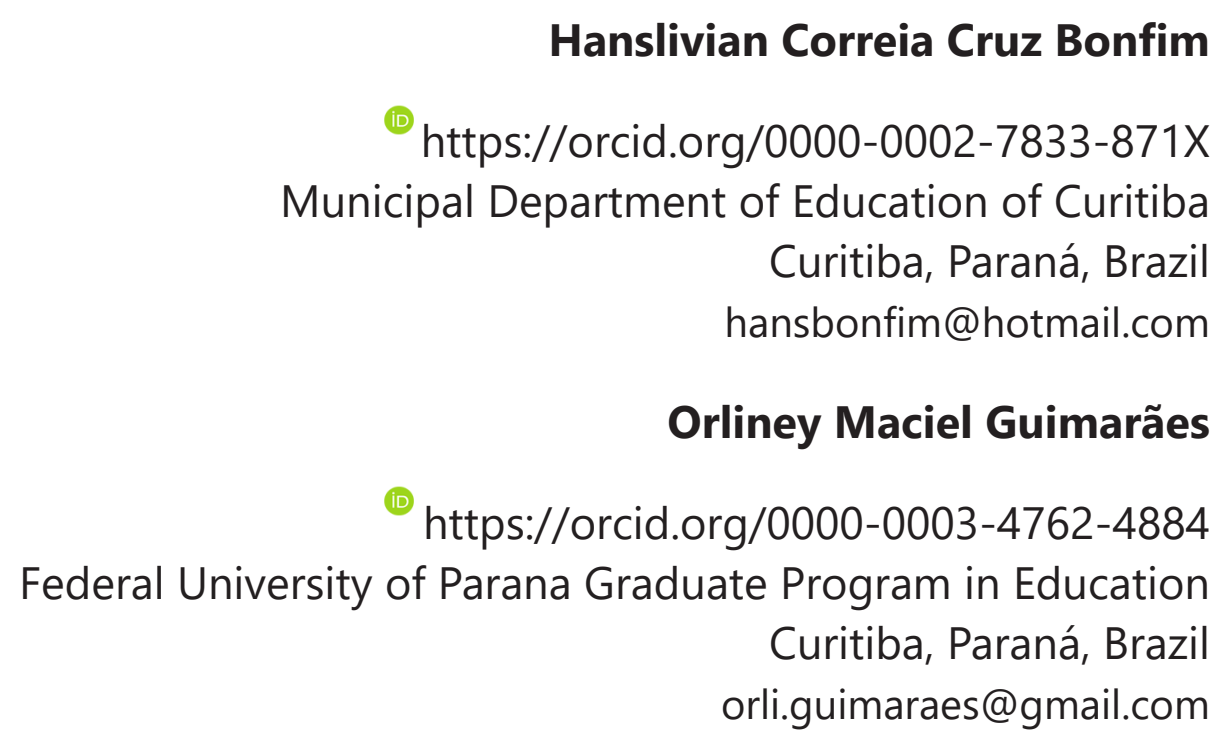

Submitted on 12th April 2020 Accepted on 14th de August 2020 Published on 16th September 2020 